UNRAM Law Review is licensed under a Creative Commons Attribution 4.0 International License, which permits unrestricted use, distribution, and reproduction in any medium, provided the original work is properly cited. p-ISSN: 2548-9267 | e-ISSN : 2549-2365, Open Access at : http://unramlawreview.unram.ac.id/index.php/ulr

\begin{tabular}{c|c|c|c|c|}
\hline Volume & Issue & Page & April & p-ISSN: 2548-9267 \\
\hline 4 & 1 & $74-83$ & 2020 & e-ISSN : 2549-2365
\end{tabular}

\title{
Legal Protection Concerning Domestic Flights Passengers of Air Transport Services
}

\author{
Sudiarto \\ Faculty of Law, Mataram University \\ Email: sudiartomataram@gmail.com \\ Budi Sutrisno \\ Faculty of Law, Mataram University \\ Email: soetrisnoboedhi@yahoo.com
}

\begin{abstract}
The aims of this paper is to discuss and analyze the legal protection concerning air transport consumers on domestic flights. The method using normative method with statute approach and conceptual approach. The results of this paper is to discuss the particular regulations on special facilities for disabilities, elderly, children under the age of 12 years and the patient are not found under the domestic flights regulation in Indonesia. The procedure in obtaining compensation to passengers who passed away because of the aircraft accident is extremely complicated. In addition, the compensation to passengers caused by the flight delays have not been optimally implemented.
\end{abstract}

Keywords: Legal Protection; Air transport; Consumer.

\section{INTRODUCTION}

Based on its geographic area and population, the role and function of air transportation have a very important and strategic position in Indonesia, both in terms of national unity, socio-cultural life, defense and security, economy and governance. Air transport is the only fast, efficient and economical alternative for inter-island and inter-regional transportation in Indonesia. ${ }^{1}$ Airtransportation is also an important instrumentto develop the tourism sector, acknowledge that Indonesia as one of the few countries which are rich in culture and natural beauty as well as its tropical climate can attract foreign tourists foreign exchange as a substitute in increasing petroleum. The air transportation role is very important, particularly in terms of politics and economics which led to development of thenational aviation world, especially passengers. The importance of this mode of transportation should be manifested by provides a good service since it requires very high cost, whether to establish the airline, to operate it, or afforded by the passengers. Services are related to:

1. Goods services on Article 97 Law No 1 of 2009 about Aviation; and

2. The right to get compensation if passengers experience a loss.

1 Sudiarto, Tanggung Gugat Pemerintah Terhadap Kecelakaan Pesawat Udara di Indonesia, Amanna Gappa, Jur nal Ilmu Hukum, Universitas Hassanuddin, Makassar, Vol, 20 Nomor 3, September 2012, p. 273. 
Both forms of services needed by air transport service passengersare essential necessaries that must be met by the air carriers. In this case, the passenger with carrier and Airline Company are related as the business actors and customersas regulated under Law No. 8 of 1999 on Consumers Protection which is then abbreviated as (UUPK), which addressed that consumers have the right in the event of transportation between business actors and consumers. In general, consumers have four general rights, namely: ${ }^{2}$

a. Right to security;

b. Right to get information;

c. The right to vote

d. The right to be heard.

These rights were adopted from Article 4 of UUPK which regulated consumer rights, including: ${ }^{3}$

a. The right to comfort, security and safety in consuming goods and/or services;

b. The right to choose goods and/or services and to obtain goods and or services according to the exchange rate and conditions and guarantees promised;

c. The right to true, clear and honest information about the conditions and guarantees of goods and/or services;

d. The right to be heard on opinions and complaints concerning goods and/or services use;

e. The right to obtain advocacy, protection, and efforts to resolve dispute protection appropriately;

f. The right to receive guidance and consumer education;

g. The right to be treated or served properly and honestly without discrimination;

h. The right to obtain compensation, compensation and/or replacement, if the goods and/or services received do not comply with the agreement or are not as intended; and

i. Rights regulated in other statutory provisions.

Consumer rights whichregulated underUUPK are applied in Law No. 1 of 2009 concerning Aviation. The Law regulates the rights of passengers ${ }^{4}$ as users of transportation services, but it does not explain in detail how the overall protection of consumers using air transport services in many cases including facilities for disabilityas well as other matters have mentioned but consumers as if they have no power if it is violated. Concerning the disable consumer, for example, there is no single aircraft serving domestic routes that provide special places for persons with disabilities as determined by the legislation. This fact shows that consumers of air transportation modes are in a weak and disadvantaged position. ${ }^{5}$

The lawsuit case by Ridwan Sumantri, one of the people with a disability, against PT. Lion Mentari as defendant I, PT.Angkasa Pura II as Defendant II and the Ministry of Transportation of the Republic of Indonesia as Defendant III in 2011, becameclear evidence of the air transport's disregard for the rights of the air carriers which should be accepted by people with disabilities. The decision of the Supreme Court No. 231/Pdt.G/2011/PN.Jkt.Pst which states that the actions of Defendant I, Defendant II and Defendant III who do not provide facilities for people with disabilities are violating the law.

2 Sidharta. (2000). Hukum Perlindungan Konsumen Indonesia. Jakarta: PT. Grasindo, p. 34.

3 Ibid.

4 Yusuf Shofie. (2009). Perlindungan Konsumen \& Instrumen Instrumen Hukumnya. Bandung: Citra Aditya Bakti, p. 227.

5 Ibid. 


\section{METHOD}

The method used in this paper is a normative method ${ }^{6}$ by using the statute approach and conceptual approach. ${ }^{7}$ The types of data in the form of primary legal materials consist of Law No. 8 of 1999 on Consumer Protection, Law No. 1 of 2009 on Aviation, and Regulation of the Minister of Transportation of the Republic of Indonesia No. 77 of 2011 on Responsibilities of Air Transport Carriers. Secondary legal material in this study is the opinion of legal experts and non-legal material is in the form of the Aviation Dictionary. The technique of collecting legal material is done by conducting literature. ${ }^{8}$

\section{ANALYSIS AND DISCUSSION}

Legal protection for the people (community or consumers or service users) in Indonesia is based on Pancasila and the Constitution of the Republic of Indonesia, because they are basic ideology and philosophy of the Indonesian people who uphold human values by placing the law as a law commander and not power. Respect in human rights and positioning the Indonesian nation as a state of the law has consequences that must be obeyed and carried out by the government as the organizer of the state.

AZ. Nasution, ${ }^{9}$, defines consumer protection as the whole of the principles and rules which govern and protect consumers in their relationships and problems with suppliers of goods and/or services. Further, Az. Nasution states that consumer protection regulation as part of consumer law which contains principle or rule that are regulatory, and also contain properties that protect the interests of consumers. Consumer law defines as the overall principle and rule governing the relationship and problem between various parties with each other relating to consumer goods and or services. The understanding put forward by this expert confirmed in Article 1 No. 1 of the UUPK, that consumer protection as an effort which guarantee the legal certainty to provide protection to consumers.

The primary function of law is to provide protection to citizens, especially those who are in a weak position due to unbalanced legal relations. Likewise with the consumer protection law to protect consumers from dishonest business actors.Consumer protection is an effort that guarantees legal certainty to provide protection for consumers. Whereas, the consumer protection law is the overall principle and rules that regulate and protect consumers in the relationships and problems in the supply and use of consumer products between their suppliers and users in social life.

Regarding business actors, public opinion usually refers to the business actors as a producer. Sometime, they interpret the producer as an entrepreneur, but there are also opinions that stated that the producer is only a producer of goods and is one element of the entrepreneur. UUPK used the term business actor instead ofan entrepreneur. Article 1 No. 3 of the UUPK mentioned that the definition of business actor shall be formulated as every individual or business entity, whether in the form of a legal entity or not who established and domiciled in the jurisdiction of the Republic of Indonesia, whether alone or together through an agreement on the implementation of activities business in various fields of economics.

6 Mukti Fajar dan Yulianto Achmad. (2010). Dualisme Penelitian Hukum, Normatif \& Empiris. Yogyakarta: Pustaka Pelajar, p. 153.

7 Peter Mahmud Marzuki. (2008). Penelitian Hukum. Jakarta: Kencana Prenada Media Group, p. 93.

8 Soerjono Soekanto dan Sri Mamudji. (2006). Penelitian Hukum Normatif, SuatuTinjauan Singkat. Jakarta: Raja Graf indo Persada, p. 43.

9 Az Nasution. (1999). Perlindungan Konsumen, Suatu Pengantar. Jakarta: DayaWidya, p. 3.

76 Sudiarto \& Budi Sutrisno | Legal Protection Concerning Domestic Flights Passengers... 
Service users are another designation for consumers specifically intended for users of modes of transportation, both land, sea, and air transportation. Since it is another name for consumers, the rights of consumers regulated in UUPK also applied to other transportation services users Indonesia, the consumer rights are regulated under UUPK as listed in Article 4 which described as:

1. The right to comfort, security and safety in consuming goods and /or services;

2. The right to choose goods and/or services and obtain said goods and/or services in accordance with the exchange rate, condition and promise of guarantee;

3. The right to correct, clear and honest information about the condition and guarantee of goods and/or services;

4. The right to be heard on opinion and complaint on goods and/or services used;

5. The right to obtain advocacy, protection, and effort to resolve consumer protection disputes appropriately;

6. The right to receive guidance and consumer education;

7. The right to be treated or served properly and honestly without discrimination;

8. The right to obtain compensation, compensation and/or replacement, if the goods and/or services received do not comply with the agreement or are not as intended; and

9. Other rights as regulated on the provisions laws and regulations.

The rights of users on air transportation services also stipulated underLaw No. 1 of 2009 on Aviation, where the rights of users of transportation services are in the form of the right to obtain services. This regulation, especially in Article 97mentioned about air transportation services. Air transport services in Indonesia are divided into three parts, namely:

1. Services with a maximum standard (full services); is the maximum form of service provided to passengers during a flight according to the type of flight service class;

2. Medium standard service (medium service); that is a simple form of service provided to passengers; and

3. Service with a minimum standard (no-frills) is a minimum form of service provided to passengers.

In addition, to getting the services as mention under Article 97 of this regulation, appropriate services also provided to users of transportation services disabilities, elderly, children and/or patients as regulated under Article 134 of this law. Special treatment services and facilities could be manifested in the form of:

1. Giving priority to additional seats;

2. Provision on facilities to get on and off of the aircraft;

3. Provision on facilities for persons with disabilities while in the airplane;

4. Facilities for helping the sick;

5. Provision on facilities for children while on airplanes;

6. Availability of personnel who can communicate with people with disabilities, elderly, children and/or sick people; and

7. The availability of manuals on flight safety and security for aircraft passengers and other facilities that can be understood by people with disabilities, elderly, and sick people.

In addition to the aforementioned articles, which become the right for air transport service users is included under Article 140 of this law, which basically requires air carriers to provide appropriate services to each air transport service user. In addition, to obtain the service rights from the air carrier, the user of the transportation service also has the right to obtain compensation from the carrier if the user of the transportation service suffers a loss due to an air carrier error. This compensation for the carrier is a form of responsibility that must be carried out by the air carrier for the loss suffered by the passenger. 
Regarding the responsibility (some works of literature use the term liability instead of accountability, including this paper $)^{10}$ air carriers are known for several principles of liability. The principle of accountability is a very important issue in the law of consumer protection (in this paper uses the term transport service users as a synonym for consumers). In general, the principle of accountability in law can be distinguished as follows:

1. Liability based on fault ${ }^{11}$ (Endang Saefullah:1989), is a fairly general principle applicable in private and public law. This principle states that someone can only be held liable if there is an element of wrongdoing. Mistake meansas an element which is contrary to the law. The definition of law is not only contrary to the law, but also propriety and decency in the society. In common sense, this principle of liability is acceptable because it is fair for the person who did wrong to compensate the victim, and it is very unfair if the innocent person has to compensate for the harm suffered by others.

2. Presumption of liability ${ }^{12}$, this principle states that the defendant is always considered responsible until he can prove he is innocent. Therefore, the burden of proof lies with the defendant.

3. Principle of absolute responsibility ${ }^{13}$, or in the literature commonly known as the expression of absolute liability which means that this kind of liabilitydoes not need to prove the existence of errors, or in other words, this liability is a form ofthe principle of liability which pointed mistake as an irrelevant to be questioned whether in fact is exist or not.

In accordance with those principle of liability, there are four variationsof the doctrine known in transportation law, namely:

1. The carrier exempted from liability if they can prove losses caused by things outside his control;

2. The carrier exempted from liability in case if they able to prove if theyare taking a necessary action to avoid the occurrence of losses;

3. The carrier exempted from liability in case they can prove if the loss arising is not due to its mistake; and

4. The carrier is not liable if the losses is caused by the passenger error or negligence as well asbecause thequality of the goods which being transported.

The reverse of burden proof also known as omkering van bewijslastseems like accepted on this principle. The rationale of the reversal theory of the burden proof is that someone considered as guilty, until the person concerned can prove otherwise. This principle is very contrary to the presumption principle of innocence which is commonly known in law. However, if it applied in the case of users of transport services, itwillaccordingly quite relevant. If this principle is applied, the one who is obliged to prove the offense will be the business party, or in this case is the air carrier, sued. Burden of proof ${ }^{14}$ (Martono2007) in air transportation oblige the airlines to prove their innocence, this known as the burden of proof reversed.

In addition, the compensation right of air transportation service, users also entitled to claim the transporter due to the delay of carrier transportation mode. Likewise, the non-transport of service users by carriers for reasons of aircraft capacity. In this case the carrier must provide compensation to service users in the form of: ${ }^{15}$

1. Redirect to other flights without paying additional fees; and/or

10 Sudiarto. (2012). Tanggung Gugat Pengangkut Terhadap Penumpang Dalam Kecelakaan Pesawat Udara Pada Pen erbangan Domestik. Surabaya: Disertasi, Universitas Airlangga, p. 24.

11 Endang Saefullah Wiradipradja. (1989). Tanggung Jawab Pengangkut dalam Hukum Pengangkutan Udara Interna sional dan Nasional. Yogyakarta: Liberty,p. 20.

12 Ibid, p. 28.

13 Ibid, p. 35.

14 Martono. (2007). Kamus Hukum dan Regulasi Penerbangan. Jakarta: Raja Grafindo Persada, p.38.

15 Article 147 Paragraph (2) Law No. 1 of 2009 about Aviation.

78 Sudiarto \& Budi Sutrisno | Legal Protection Concerning Domestic Flights Passengers... 
2. Provide consumption, accommodation and transportation costs if there are no other flights to the destination.

Regarding to the responsibilities of air carriers in Indonesia, it is referenceto the Law No. 1 of 2009 on Aviation which regulated the responsibility of the carrier for passengers from Article 141, Article 146, and Article 147. Article 141 regulated the responsibility of air carrier for the losses of passenger who die, permanently disabled, or injuries resulting from air transport accident and/or aircraft flight.

Article 146 of this law regulated the responsibility of air carriers for losses suffered due to delays in transporting passenger, baggage or cargo, except if the carriers can prove that the delay was caused by weather and operational technical factors. While Article 147 regulated the responsibility of air carrier for not transporting passengers, according to a schedule determined by aircraft capacity. The form of air carrier responsibility is to divert to another flight without paying additional fees; and/or provide consumption, accommodation, and transportation costs if there are no other flights to the destination.

The implementation of Law No. 1 of 2009 on Aviation, the responsibility of air carrier, the Government of the Republic of Indonesia, in this case, the Minister of Transportation of the Republic of Indonesia on $8^{\text {th }}$ August 2011 issued Minister of Transportation Regulation No. 77 of 2011 concerning The Responsibility of Air Transport Carrier. The provision listed under Article 141, Article 146 and Article 147 of Law No. 1 of 2009 which are implemented in Article 3, Article 9, Article 10, Article 11, Article 12, and Article 13 of the Minister of Transportation Regulation of the Republic of Indonesia Number 77 of 2011. The implementation of Article 141 of Law No. 1 of 2009 contained in Article 3 of the Regulation of the Minister of Transportation of the Republic of Indonesia stated that for the losses of the passenger who died in an aircraft due to an airplane accident or incident solely related to air transportation, compensation is given IDR 1,250,000,000 (one billion two hundred and fifty million rupiah) per passenger.

Passengers who die during embarkation and disembarkation processes, both at the destination airport and at the transit airport are compensated for IDR500,000,000 (five hundred million rupiah). Passengers who have permanent disabilities get IDR 1,250,000,000 (one billion two hundred and fifty million rupiah) per passenger as compensation, while passengers who are injured are compensated for as much as the real and highest maintenance costs of IDR 200,000,000 (two hundred million rupiah).

The implementation of provisions in Article 146 and Article 147 of Law No. 1 of 2009 about Aviation, can be seen in Article 9, Article 10,Article 11, Article 12 and Article 13 of the Minister of Transportation Regulation of the Republic of Indonesia No. 77 of 2011 on Responsibilities of Air Transport Carriers. Article 9 basically regulated on the delay in air transportation consisting of flight delayed, denied boarding passengers, and cancelation of flight. The amount of compensation for passengers caused by flight delays of four hours or more is IDR 300,000 (three hundred thousand rupiah) per passenger. For delays caused by denied boarding passengers, the carrier must divert to another flight without paying additional fees and/or providing consumption, accommodation, and transportation costs if there are no other flights to the destination. Whereas passengers who experience a cancelation of flight are regulated in Article 12 which basically regulates if a flight is canceled, the carrier is required to notify the passenger no later than seven calendar days prior to the flight by returning all ticket money paid by the passenger.

Article 13 of the Minister of Transportation of the Republic of Indonesia Regulation Number 77 of 2011 regulated the exemption of air carriers for compensation due to flight delays due to the weather and/or operational technical factors. Weather factors include heavy rain, lightning, storms, fog, smoke, visibility below standards that interfere the flight safety. Whereas what is 
meant by operational technical factors include airport for departure and destination, aircraft operation unavailable to be used, the environment to the airport or runway is disrupted due to the cracking, flooding, or fire. Other operational techniques can also be caused by aircraft takeoff or landing queues, or departure slot time or also due to refueling.

\section{Consumer Rights in Air Freight:}

1. Good Service Rights;

Article 134 of Law No. 1 of 2009 about Aviation expressly grants special service rights in the form of special treatment and facilities for persons with disabilities, elderly, and children under 12 years, and sick people from air transport business entities. Minimum service facilities and special services are detailed in Article 134 Paragraph (2) of Law No. 1 of 2009 onAviation. The description of this special facility become a reference for researchers in conducting research and the results are described as follows:

a. Providing priority to additional seats for people with disabilities, elderly people, children under the age of 12 years, and for the sick. This facility is not found yet in aircraft on domestic flights. A person witha disability such as passengers who cannot walk at the time of embarkation and disembarkation is only helped using a wheelchair who is pushed by airline officials. Special seats determined by legislation are not found in aircraft, even to be able to sit in a place that helps at ease for passengers with disabilities, usually on the sincerity of other aircraft passengers to give their seats used by a passenger with disabilities. During the study, researchers found that there was no coordination between the airline officials who is on the check-in duty with the family of the disabled passenger on the seat placement, while the Elderly in accordance with Law No. 1 of 2009 on getting priority seat in aircraft did not found in Indonesia domestic flights. Elderly passengers often placed on the rear of the aircraft seat, which is less comfortable for the elderly passengers since the type ofaircraftin Indonesia is Boeing and Airbus where the engine position right at the rear of the aircraft which caused the noise of the aircraft engine quite disturbing for passengers.Furthermore, the children passengers who areunder the age of 12 years who supposed to get the special seat services on an airplane are treated equally as adults, only distinguishing that children underthree years old are provided with seat belt and the other facilities are the same, even the ticket price for children who is over two years old have the same price as the adult ticket price, while the ticket price for children under two years must be paid half of the adult ticket price. Moreover, the special facilities such as a special seat for the sick in Indonesia domestic flights are not provided. For the sick people who use a thrust bed due to impossible conditions to sit, the sick passengers will not be transported by regular airlines, but they must charter an airplane which suitable for this particular condition.

b. The provision on facilities to get on and off the aircraft have not provided, possibly since the type of the aircraft operated in Indonesia was not equipped with special facilities for boarding and alighting from aircraft. Aircraft passengers with disabilities, such as passengers who cannot walk when going up and down the stairs of the aircraft, or when using aviobridge, passengers who cannot walk are carried by airline carriers to sit on passenger seats and likewise when he was about to get off the passenger plane was carried by the airline staff and sat in a wheelchair and then pushed to exit the arrival building.

c. The provision of facilities for persons with disabilities while in the airplane; all aircraft operating in Indonesia do not have special facilities onboard for the physically challenged. This is because the type of aircraft operating in Indonesia is classified as a medium-sized aircraft because the number of seats for one aircraft is at maximumof 210 seats, namely the type of Boeing 900 ER. The types of commercial aircraft operating in Indonesia almost entirely for 
business purposes only, therefore the number of seats was created only to accommodate a large number of passengers, without concern on the special facilities as determined by the statutory regulations.

d. Support facilities for the sick; for passengers who are seriously ill, there are no special facilities available on commercial aircraft in Indonesia. As with disabled passengers, elderly people are not provided with special facilities as required by law and regulations. If the sick passenger wants to depart using special facilities, then the passenger has to charter the aircraft themselves, which definitely cost expensive money.

e. The provision on special facilities for children on board; For a children passengers who are under 12 years old, provides no special facilities on the airplane. The only special equipment is for the passengers under the two years old which is provided by a small seat belt which is separate from the regular seat and when the plane arrived the seat belt will be returned to the airplane officer.

f. The availability of official who is able to communicate with disabilities, elderly, children, and/or sick people; forthe passengers with disabilities, Passengers mentioned above when traveling by airplane, he must be accompanied by his family or medical personnel such as doctors and nurses which in the responsibility to the passengers themselves.

g. The availability of manuals on flight safety and security for aircraft passengers and other facilities which can be understood by people with disabilities, the elderly. General safety and security manuals are provided onboard the aircraft in each passenger seat. The flight crew demonstrates how to use seat belts, masks, and protectors during an accident.

2. The Right to Get Compensation for Losses

According to Law No. 1 of 2009 onAviation, thepassengerhas theright togetcompensation if they suffer losses. Article 141 Paragraph (1), Article 146 and Article 147 of Law No. 1 of 2009 instructed each airline to be held on responsible for losses suffered by passengers in terms of:

a. Passenger dies; follow-up to the provisions of Article 141 (1) Law No. 1 of 2009 on Aviation, the Minister of Transportation of the Republic of Indonesia issued MinistryRegulation No. 77 of 2011 concerning The Responsibility of Air Transport Carriers. According to this ministerial regulation, if a passenger dies on board due to an airplane accident, they will be compensated forIDR 1,250,000,000 (one billion two hundred and fifty million rupiah). In practice, the compensation is given by the air carrier to the heirs of the victim with a long time and complicated procedures. For example is the accident by Air Asia Indonesia aircraft flight code QZ 8501 route Juanda Airport Surabaya to Changi Airport Singapore at 07.55 West Indonesia Time on December 28, 2014. The compensation process for passengers who died until now has not been completed by Air Asia Indonesia. In providing the compensation Rp. 1,250,000,000 (one billion two hundred and fifty million) rupiah, the air carrier cannot evade it, because Article 141 (1) of Law No. 1 of 2009 applies the Absolute Claims Principle. Thus, the carrier must pay compensation for passengers who died.

b. Permanently handicapped passengers; passengers who experience a total permanent disability by a doctor within a period of no later than 60 (sixty) working days since the occurrence of an aircraft accident get compensation of IDR 1,250,000,000 (one billion two hundred fifty million) rupiah. Total permanent disability here such as total vision loss from two incurable eyes, or severance of two hands or two legs or one hand and one foot or above the wrist or foot, or total loss of vision from one eye that cannot be cured and one broken hands or feet above the wrists or ankles. Whereas, passengers who are declared partially disabled by the doctor within 60 working days of an aircraft accident 
are compensated varies depending on the defect they suffer. As of this writing up to this writing, there have been no aircraft accidents where passengers have survived.

c. Passenger injuries; passengers who are injured and must undergotreatment in hospital, clinic or clinic as an inpatient or outpatient are compensated for the real cost of treatment at most IDR 200,000,000 (two hundred million rupiah). In practice, there have not been any passengers who experienced this condition, since the issuance of the Minister of Transportation Regulation No. 77 of 2011 in Indonesia there has never been any accidents in an aircraft whose passengers have survived. The provision of compensation to victims of aircraft accidents in Indonesia is very complicated, for example is victims of Air Asia aircraft accident which crashed in the Karimata Strait on 28 December 2014, until today all the victims have not received the compensation from Air Asia.

d. Passengers experience delays; in practice, passengers who experience delays of more than four hours are compensated for IDR 300,000 (three hundred thousand rupiah). However, some of the money was given by the airline in cash, some were given in the form of transfers to an account in the name of the passenger. Giving by transfer to an account in the name of the passenger is very detrimental to the passenger because there has been no realization of this kind of compensation. The loss of passengers who experience delays of less four hours in practice so far is if the delay is less than one hour, then the passengers get food and soft drinks, whereas if the delays are more than one hour and less than three hours, each passenger gets consumption in the form of food (rice boxes) and drink. However, thereason for the delays is caused by weather factors and/or due to operational technicalities.

e. Flight cancellation; for losses caused by flight cancellations so far caused by natural factors such as volcanic eruptions, smoke factors that cause limited visibility so that flight cancellations occur. Passengers are given the choice of returning the entire ticket price or waiting for the flight at an uncertain time. For passengers who choose to divert departure by using mixed modes of transportation such as some using land, sea, and air transportation modes, then it is entirely the responsibility of the air carrier.

\section{CONCLUSION}

According to the description above, it can be concluded as follows:

1. Legislation concerning particular services for disabled passengers, elderly people, children under the age of 12 years and sick people in obtaining special facilities from aviation business entities have not found in domestic air transportation in Indonesia.

2. The procedure for obtaining compensation to passengers who died as a result of an aircraft accident in Indonesia is very complicated.

3. Compensation for aircraft passengers in Indonesia due to delays has not been optimally applied, especially for the provision of compensation as a result of the delay in departure more than four hours.

\section{Bibliography}

Books

Fajar, Mukti, Yulianto Achmad. (2010). Dualisme Penelitian Hukum Normatif \& Empiris. Yogyakarta: Pustaka Pelajar.

Nasution, AZ. (1999). Perlindungan Konsumen, Suatu Pengantar. Jakarta: DayaWidya. 
----, 1995, Konsumen dan Hukum: Tinjauan Sosial Ekonomi dan Hukum pada Perlindungan Konsumen Indonesia. Jakarta: Pustaka Sinar Harapan

Shidarta. (2000). Hukum Perlindungan Konsumen Indonesia. Jakarta: Grasindo.

Shofie, Yusuf. (2009). Perlindungan Konsumen \& Instrumen Instrumen Hukumnya. Bandung: Citra Aditya Bakti.

Soekanto, Surjono dan Sri Mamudji. (2006). Penelitian Hukum Normatif, Suatu Tinjauan Singkat. Jakarta: Raja Grafindo Persada.

Sudiarto. (2012). Sudiarto, Tanggung Gugat Pengangkut Terhadap Penumpang Dalam Kecelakaan Pesawat Udara Pada Penerbangan Domestik. Surabaya: Disertasi, Universitas Airlangga.

Martono. (2007). Kamus Hukum dan Regulasi Penerbangan. Jakarta: Raja Grafindo Persada.

Marzuki, Peter Mahmud. (2008). Penelitian Hukum. Jakarta: Kencana Prenada Media Group.

Wiradipradja, Endang Saefullah. (1989). Tanggung Jawab Pengangkut dalam Hukum Pengangkutan Udara Internasional dan Nasional. Yogyakarta: Liberty. 